Wiestaw Andrukowicz

Uniwersytet Szczeciński

\title{
Analiza ramowa rzeczywistości według Ervinga Goffmana
}

\begin{abstract}
Erving Goffman's frame reality analysis

This article is presenting Erving Goffman's multilayer and polysemy reality analysis and analysis of our real and symbolic social life. This analysis should provoke a reader to think about world we are living (full of interaction rituals and dictated interpretation schemas) but first of all to think how to create and develop a man succeed in a world of paradox of being actor and a spectator.
\end{abstract}

Key words: frame analysis, reality, game, stage, performance

Słowa kluczowe: analiza ramowa, rzeczywistość, gra, scena, występ

\section{Wprowadzenie}

Na ogół przyjmuje się, że to, co naprawdę istnieje (niezależnie od naszego podmiotowego widzimisię), jest rzeczywistością, a to, co jest kłamstwem, zmyśleniem, fałszem i złudzeniem, jest udawaniem rzeczywistości. Nie wchodząc zaś w szczegóły, można powiedzieć, iż prawda oznacza możliwie maksymalną zbieżność naszego przedstawienia rzeczy z rzeczą samą w sobie, dlatego że brak identyczności łączy się z nieusuwalnym prawem ambiwalencji, powodującym, że zbliżenie się do rzeczy samej w sobie (czasoprzestrzennie) utrudnia (czasami uniemożliwia) jej ujęcie logiczne i dyskursywne na korzyść estetycznego i intuicyjnego, natomiast oddalenie się od rzeczy (uogólnienie) daje rezultaty odwrotne, czyli ułatwia znalezienie koniecznych i wystarczających warunków do tego, by stało się możliwe dane sformułowanie i przedstawienie w sensie lo- 
gicznym i dyskursywnym. Co oznacza, że prawda jest uwikłana w rzeczywisty dramat szczególnego istnienia i ogólnej istoty rzeczy.

Brak świadomości tego dramatu uniemożliwia zrozumienie faktu, jak zauważył chociażby Martin Heidegger, iż podstawą prawdziwości nie jest „bezwzględna zgodność" zobiektywizowanego sądu z obiektywnym stanem rzeczy, lecz „odkrywczość” sposobu i miejsca w „prześwicie” bycia (mówiąc na marginesie, „odkrywanie” konkretnego sposobu i miejsca nie musi zaprzeczać „uzgadnianiu” ogólnej istoty i odwrotnie). Jakkolwiek interpretować „odkrywanie" prawdy, która w całości jest dla podmiotu zakryta, to swoisty apel Heideggera jest zrozumiały (choć niekompletny) i zachęca do przełamania uproszczonego (by nie powiedzieć prostackiego) sposobu postrzegania rzeczywistości, w którym na co dzień nie stykamy się z samą rzeczą, ale z jej „pośrednikiem” (obrazem, sygnałem, symbolem i słowem). „Pośrednik” jednak, zwłaszcza język werbalny, zamiast roli adwokata, rozjemcy czy mediatora starającego się doprowadzić do zgody i porozumienia między rzeczą a nami, w coraz bardziej abstrakcyjnej formie oddala nas od niej (paradoksalnie „precyzja języka ogranicza jego ontykę").

Stąd w bezosobowym i abstrakcyjnym przedstawieniu rzeczy jest zdecydowanie łatwiej zamieniać „prawdę istnienia” na „istnienie prawdy”. „Obowiązująca prawda” zaś bez większych przeszkód przenika w czas i przestrzeń (zwłaszcza w myślenie i działanie kulturowe nieświadomych tej złożonej struktury podmiotów), stając się realnym światem społecznych interakcji. Zatem jeśli „rzeczywistość” ograniczymy do tego, co ogólnie wiemy (bez świadomości uczestniczenia w dramacie rzeczy i przedstawienia, bez próby odróżniania tego, co w nas i ponad nami), to musi mieć ona charakter apodyktyczny i zamknięty, a nie ciągle aproksymatywny i otwarty.

Dlatego już Heraklit zauważył, że bez swoistej „walki” konkretnego i ogólnego nie docieramy do prawdy, która jest osiągana przez walkę, a nie jako dar. Platon poszedł jeszcze dalej i zwrócił naszą uwagę na to, iż nie ma jednej rzeczywistości, lecz wszystko dzieli się na niezmienny (ogólny) i zmienny (konkretny) typ rzeczy ${ }^{1}$. Ten pierwszy jest samoistny (np. idea „trójkąta równoramiennego" ma obiektywny sens, nie zależy bowiem ani od naszej realnej percepcji, ani od naszego subiektywnego zmyślenia, ponieważ trwa również wtedy, gdy o niej nie myślimy, a jeśli myślimy, to oddziałuje na nas oraz na inne podmioty

\footnotetext{
1 „Kiedy tak się rzeczy mają, to zgodzić się trzeba, że istnieje jeden rodzaj rzeczy, niezmienny, niezrodzony i nieginący, który ani w sobie nie przyjmuje niczego skądinąd, ani sam w nic innego nigdzie nie przechodzi, niewidzialny i w żaden inny sposób niedostrzegalny - oglądać go może tylko myśl rozumna. I drugi rodzaj rzeczy nazwany tak samo i podobny do tamtego, spostrzegalny, zrodzony, zmienny ustawicznie, który powstaje w pewnym miejscu i znowu stamtąd przepada uchwycić go potrafi mniemanie (opinia) i spostrzeżenie" (Platon, 1951, s. 51-52).
} 
w ten sam sposób, chociaż jest poza przeżywanym czasem i przestrzenią), ten drugi jest jedynie jego cieniem („ruchomym obrazem wieczności”).

Kartezjusz, który w pewien sposób kontynuował projekt pluralizmu bytowego Platona, wyróżnił z kolei niezależną od siebie rzeczywistość materii i duszy, ta ostatnia niestety sprowadzona tylko do myśli, które były dla niego "czymś” rzeczywistym, chociaż nieistniejącym tak jak ciała materialne ${ }^{2}$. Immanuel Kant natomiast, nie mogąc ominąć z jednej strony sceptycyzmu (wobec uproszczonego idealizmu) Davida Hume’a, z drugiej strony zaś wyzwania dla naiwnego realizmu, mógł stwierdzić, iż nie jesteśmy w stanie dotrzeć bezpośrednio do rzeczywistości samej w sobie (a przynajmniej nie można jej dowieść, nie istnieje bowiem żaden sąd prawdziwy, który mógłby potwierdzić jej istnienie), dlatego musi istnieć nieprzebyta przepaść między rzeczywistością „noumenu” i „fenomenu”. „Usprawiedliwienie nieobecności” rzeczy samej w sobie spotkało się z kolei z totalną krytyką i próbą karkołomnego zasypania tej przepaści przez Georga W.F. Hegla w postaci absolutnej jedności rzeczywistości, gdzie pierwotna jest myśl, a to, co widziane, jest jej wytworem. To ostatnie jednak nie tylko nie zamknęło sprawy, lecz stało się przysłowiową puszką Pandory, z której wypłynęły różnorodne, w tym przeciwstawne koncepcje rzeczywistości.

Między innymi Karol Marks odwrócił relację zaproponowaną przez Hegla i u tego pierwszego to materia jest pierwotna, a myśl stanowi jej „nadbudowę”, bez względu jednak na realistyczne czy idealistyczne podejście do rzeczywistości jedni i drudzy nie mogli pozbyć się wiary w istnienie „naturalnej” czy raczej „neutralnej” procedury identyfikowania, wyjaśniania i rozumienia treści naszych wrażeń, spostrzeżeń, wyobrażeń i myśli. Dlatego między innymi Bronisław F. Trentowski (przyjmując za Kantem, że z jednej strony bezpośrednie dotarcie do rzeczy samej w sobie jest niemożliwe, a z drugiej sama wiedza na temat sądów apriorycznych jest bezowocna ${ }^{3}$ ) wprowadził pojęcie „rzeczywistości” i „realności” (nie dualistycznie, jak u Kartezjusza, ale dwuaspektowo, we wzajemnym dookreśleniu, inaczej jednak niż u Benedykta Spinozy, wyróżniał bowiem immanentną i potencjalną „jedność” bytu stworzonego oraz

\footnotetext{
„Szczególnie godny uwagi wydaje mi się przy tym fakt, że znajduję w sobie niezliczoną ilość idei pewnych rzeczy, o których nie da się powiedzieć, że są czystą nicością, chociażby nie miały one żadnego istnienia poza moim myśleniem, idei, których jednak sam nie zmyśliłem, jakkolwiek myślenie bądź niemyślenie ich zależne jest od mej woli, a które mają swe prawdziwe i niezmienne natury. (...) Wobec tego są one czymś, a nie czystą nicością - jest bowiem całkiem oczywiste, że wszystko, co jest prawdziwe, jest zarazem czymś [a prawda jest tym samym, co byt]" (Kartezjusz, 2006, s. 63-64).

3 Jak zauważa współcześnie Michael Dummett: „Błąd Kanta polegał na założeniu, że w wyniku analizy nie da się uzyskać niczego nowego; w ten sposób sprowadził prawdy analityczne do rangi banałów" (Dummett, 1998, s. 314).
} 
transcendentną i aktualną „Jedyność” bytu stwarzającego), gdzie rzeczywistość obejmuje całość „materialnego ducha”, natomiast realność zostaje zredukowana tylko do materii ${ }^{4}$, idealność zaś do samego ducha.

Jego zdaniem zarówno „jaźń poznająca”, z jednej strony zmysłowa, skupiona przede wszystkim na tym, co realne, zmienne, zewnętrzne i szczegółowe, $\mathrm{z}$ drugiej strony umysłowa, odniesiona do tego, co idealne, niezmienne, wewnętrzne i ogólne, jak i ,jaźń tlejąca” z jednej strony skupiona na subiektywnych odczuciach, $\mathrm{z}$ drugiej zaś na obiektywnych skłonnościach, niezależnie od siebie nie docierają do rzeczy samej w sobie, dopiero „jaźń działająca”, czyli swoisty „mysł” lub „miot” oscylujący między ciszą obserwacji i mozolnego rekonstruowania faktu a wrzawą dyskusji i atrakcyjną promocją konstruowanych teorii oraz między odczuciem istnienia a intuicją istoty rzeczy, dociera do sedna rzeczywistości jako takiej. Zatem rzeczywistość nie była u niego ani „jednią”, ani „różnią”, tylko „różnojednią” eksploracji fizyki i metafizyki, historii i teorii.

Jeśli przyjmiemy, że „rzeczywistość” w wymiarze materialnym jest tym, co zostało faktycznie zaktualizowane w czasoprzestrzeni, co stawia nam i innym przedmiotom energetyczny opór i nieredukowalną sekwencję przyczyn i skutków (bez możliwości odwrócenia w czasie), to przecież jej przedstawienie musi ocierać się o dramat, bo tylko Bóg wie, co jest w niej stworzone i stwarzające, porządkujące i porządkowane, co jest informacją, a co jej nośnikiem. W rezultacie możemy ujmować wszelką różnicę świata realnego tylko jako relatywną wobec świata idealnego, ze swoim wiecznie niezaspokojonym pragnieniem i poczuciem absolutnej jedności ${ }^{5}$.

Co nie musi oznaczać, że wszystko jest względne $e^{6}$ (nawet w przeżywanym czasie), ponieważ już uświadomienie sobie tej relacji staje się znakiem (słowem, symbolem, obrazem, sygnałem) obecności „jednego”, realnie inicjującej proces jednoczenia (coś jest bliżej i coś jest dalej ideału rzeczy, nawet jeśli ide-

4 Nie można współcześnie zamykać oczu na tezę głoszoną przez fizyków, że: „Materia nie jest dana. W świetle dzisiejszych poglądów musi być dopiero zbudowana na podstawie bardziej fundamentalnego pojęcia wyrażonego w kategoriach pól kwantowych" (Prigogine, Stengers, 1990, s. 307).

$5 \mathrm{Z}$ interesującą interpretacją prawdy i rzeczywistości wystąpił Francis H. Bradley, który twierdził, iż nie powinny nas zadowalać opisy rzeczywistości dokonane w kategoriach przedmiotów znajdujących się w czasie i przestrzeni, bo przy wnikliwszej analizie wykazują one sprzeczności, a „ostateczna rzeczywistość nie może zaprzeczać sobie”, zatem dostęp do całości, w której wszystko jest z sobą powiązane, osiągamy jedynie przez „czucie” absolutnej jedności, które jest pierwotne w stosunku do myśli. Jego zdaniem prawda różni się od rzeczywistości, o ile stanowi jej pewien aspekt (o ile jest jednostronna), podczas gdy rzeczywistość ze swej istoty jest „wszechogarniająca” (Bradley, 1914, s. 116-117).

6 „Relatywne terminy (szczególnie pejoratywne) wymagają korelatów, bo inaczej same okazują się pozbawione znaczenia” (Berlin, 1994, s. 157). 
ałem jest to wszystko, co przerasta dostępne środki wyrazu, mimo to powinno być wyrażone, a nie roztropnie niedostrzegane lub prewencyjnie tłumione). Zresztą gdy chodzi o doskonalenie człowieka, każdy ideał o rysach prawdopodobieństwa jest sprawą najwyższej wagi, mimo że sam proces (jednoczenia) nigdy nie pozbędzie się podziału na możliwość i akt, istotę i istnienie, a zatem nie zdobędzie tu i teraz statusu absolutu, to nie jest również działaniem pustospełnionym, beznadziejnym, ponieważ absolutna jedność budzi w nas impulsy i motywy swego zaistnienia, bez których nikt nie przekroczyłby samego siebie, by być paradoksalnie jeszcze bardziej zjednoczonym z sobą jako innym.

Dlatego człowiek dramatycznie miota się między różnicą a jednością i nic go nie zadowala do końca, zawsze chce więcej i zawsze idzie dalej, czy to w realu, czy to w symbolu, bezustannie integrując się w zgodzie (lub niezgodzie), jak również dezintegrując się, aż do rozpadu, kiedy dezintegracja bierze górę nad integracją. Bez różnicy nie ma odkrywczości i rozwoju, bez jedności nie ma porozumienia i stabilizacji, jedno i drugie odsłania implikacje tego, co rzeczywiste. W rezultacie (możliwości jednoczenia i różnicowania) ten fenomen życia społecznego musi ocierać się o rzeczywisty i udawany porządek bądź o spontaniczność rzeczywistą i udawaną, a to oznacza, że człowiek musi być istotą dramatyczną.

Być istotą dramatyczną znaczy: przeżywać dany czas, mając wokół siebie innych ludzi i ziemię jako scenę pod stopami. Człowiek nie byłby egzystencją dramatyczną, gdyby nie te trzy czynniki: otwarcie na innego człowieka, otwarcie na scenę dramatu i na przepływający czas (Tischner, 1998, s. 7-8).

Doświadczenie „innego” oznacza na ogół doświadczenie tego, co jest naprawdę poza mną, mimo prób narzucania innym swojego widzenia rzeczywistości i mimo że czasami inny jest tylko skutecznym i atrakcyjnym „aktorem” ukrytym pod (przyciągającą uwagę) maską, a rzeczywiście jest takim samym, niczym istotnym nieróżniącym się od nas samych, którzy w tym samym czasie i miejscu przeżywamy na tej samej scenie podobny scenariusz życia. „Jesteśmy, jacy jesteśmy, poprzez siebie. I poprzez siebie jesteśmy tam, gdzie jesteśmy. Tak rozwijamy nasz dramat - na dobre i na złe" (Tischner, 1998, s. 114). Oznacza to, że relacja Ja i Ty istnieje wyłącznie we wzajemnym odniesieniu do siebie. W życiu społecznym nie ma Ja całkowicie pozbawionego Ty oraz odwrotnie, Ja nie może się zaś ukonstytuować samoistnie, jeśli nie zostało zapytane jako Ty. Dopiero w pytaniach, dialogu, sporze i walce o jedność tworzy się Ja istoty samoistnej, odrębnej od innego.

Zasygnalizowane tu elementy swoistej „filozofii dramatu” niewątpliwie zainspirowały twórczość amerykańskiego socjologa Ervinga Goffmana, który porównał interakcje Ja-Ty-My-Oni do teatru, to znaczy zachęcał nas, by spojrzeć na życie społeczne, tak jak gdyby było teatrem, w którym toczy się rzeczy- 
wista gra i gra na niby, w którym przeplatają się różne warianty rzeczywistości obiektywnej i subiektywnej, realnej i idealnej.

\section{Rzeczywista gra natury i kultury}

Nie ulega żadnej wątpliwości, że organizacja naszego życia nie jest ani pasmem przypadkowych zderzeń z przedmiotami i podmiotami, ani do końca zaplanowanym i precyzyjnie urzeczywistnionym scenariuszem codziennych interakcji, lecz po części kierowaną określonym modelem ${ }^{7}$ interpretacji świata, dostępnym indywidualnie, po części spontaniczną współpracą z okolicznościami, w której sama gra i ustalanie jej reguł odbywa się jednocześnie, a wersje rzeczywistości są nie tylko różne we wzajemnym dookreśleniu, ale również w znoszeniu bądź nakładaniu na siebie. Właśnie dzięki temu mniej lub bardziej ogólnemu modelowi możemy wyjaśniać i próbować zrozumieć konkretne sytuacje i wypowiedzi innych, a także zasugerować innym sens własnej aktywności podejmowanej w sferze publicznej. Inaczej można powiedzieć, iż taki model jest swoistą mapą świata, który pozwala orientować się w chaosie toczących się zdarzeń oraz interpretować wszystkie zauważone bodźce i reakcje (w tym również te spoza modelu).

Chcemy tego, czy nie, kooperacyjny charakter naszego zbiorowego życia formuje nasze zachowania, odrywając od naturalnych reakcji naszego psychofizycznego organizmu i „wprasowując” w reakcje uwarunkowane socjokulturowo. W tym sensie trochę racji miał Jean-Jacques Rousseau, że zamiast odnosić się do tego, co rzeczywiście czujemy i widzimy tu i teraz, uciekamy od natury siebie w sztuczną postać i rolę, którą chcą w większości przeżywać i widzieć inni, czyli w pewnym sensie musimy grać zgodnie z socjokulturo-

7 Przyjmuję, że modelowanie to przedmiotowe wykrycie a posteriori lub podmiotowe ustanowienie a priori jakiegoś podobieństwa i porządku w naszym myśleniu o świecie lub działaniu w świecie, a jednocześnie odrzucenie lub zredukowanie jakiegoś chaosu i przypadkowości. W związku z tym mogą funkcjonować zarówno modele bezwzględnie zamknięte (hiperutopijne) odrzucające wszelką różnicę i spontaniczność, jak i modele bezwzględnie otwarte (hiperrealistyczne), a także modele względne (raczej otwarte lub raczej zamknięte) charakteryzujące się swoistym połączeniem idealizmu i realizmu. Konstruowanie i rekonstruowanie tych modeli, dzisiaj spadające przede wszystkim na naukę, jest najlepszym sposobem przystosowania się człowieka do optymalnego trwania i doskonalenia. Nawet jeśli czasami odbiegają od oryginału, to nie należy tego uważać za katastrofę, a jedynie za szansę, nie tylko coraz bardziej racjonalnej wiary, że budowane modele są coraz bliższe rzeczywistości, lecz racjonalnej nadziei, że nie tylko świat odciska swe piętno na człowieku, który staje się jego „produktem”, lecz także człowiek oswaja świat wartościami pierwotnymi dla niego i świata, które nie tyle radykalnie niwelują, ile realnie łagodzą kosmiczny dramat. 
wym scenariuszem niezależnym od własnych pragnień i oczekiwań (uprawiać "grę w przebranie”, a nie "grę jako grę", jak stwierdziłby Hans-Georg Gadamer). Przynajmniej bardzo dużo robimy, by nasza wersja aktualizacji siebie nie odbiegała istotnie od wersji, której oczekują inni. Rodzi to wszechobecną umiejętność „stwarzania pozorów” (lub przynajmniej gry na czas), której podstawą jest nie tyle realna i potencjalna sprawność psychofizyczna, ile skuteczność symbolicznej promocji, by przekonać innych do „kupienia” pożądanego wizerunku.

Już Szekspir napisał, że „świat jest teatrem, aktorami ludzie”, w którym często jesteśmy sterowani od zewnątrz, by nie tyle coś znaczącego „wygrać” dla siebie lub innych, ile „dobrze zagrać” swoją rolę zgodną z przyjętym scenariuszem i warunkami sceny, czyli wywrzeć (wobec presji zewnętrznej stereotypów, norm, rytuałów itp.) jak najlepsze wrażenie na widzach. Dlatego najczęściej nie skupiamy się na autotelicznej wartości „oferty” naszego myślenia i działania kulturowego, lecz na tym, co „świat kupi”, a to wymaga przede wszystkim udawania, przebierania się za kogoś innego, nakładania modnej lub wygodnej maski, szczególnie, że inni „przebierańcy” obecni w tej grze tworzą zarazem partnerów i widownię.

Jeśli nawet nie ma gotowego i doskonałego dla wszystkich scenariusza życia, to i tak jego „teatralność” może w istotny sposób skupić się na dostępnym modelu interpretacji codziennych sytuacji „twarzą w twarz”, czyli odpowiedzieć na pytanie: Jakie kategorie naszego myślenia i działania kulturowego umożliwiają analizę określonych sytuacji interakcyjnych? W związku z tym taka analiza jest $\mathrm{w}$ tym przypadku próbą zakreślenia ramy dla powszechnego zrozumienia dostępnych $\mathrm{w}$ naszym społeczeństwie znaków i znaczeń, które umożliwiają nadawanie określonym wydarzeniom priorytetów oraz monitorowanie słabych punktów i wyzwań, na jakie te ramy odniesienia są podatne. Co może czasami oznaczać, że ze specyficznego punktu widzenia jednostki to, co tu i teraz, jawi się jako rzeczywiste wydarzenie, może tak naprawdę być banalnym żartem, chorobliwym złudzeniem, przypadkowym błędem, nieporozumieniem, zinstytucjonalizowanym kłamstwem, zwykłym oszustwem, "quasi-przedstawieniem teatralnym" itd.

Musimy zatem zwrócić naszą uwagę na to, co sprawia, że nasze poczucie tego, co się dzieje na naszych oczach, jest tak wrażliwe na potrzeby tych różnych (re)interpretacji. W związku z tym nieprzypadkowo pierwszym elementem (przyjętej w tym opracowaniu analizy) będzie fenomen "aktora i widza”, „sceny i występu”, drugim zaś pojęcie „modelu i ramy”, „transpozycji i fabrykacji”, będących swoistą „mapą” umożliwiającą w miarę sprawne poruszanie się w podstawowej ofercie znaków i znaczeń, a także dającą określonym osobom oraz grupom możliwość adekwatnych reakcji oraz badanie organizacji 
doświadczenia w tych właśnie kategoriach. Mówiąc inaczej, każda interpretacja wydarzenia i wypowiedzi odbywa się za pomocą pewnych kategorii ujętych całościowo w "scenę", „scenariusz”, „rolę" i „grę”, które ostatecznie stanowią o naszej naturze i kulturze bycia.

\section{Fenomen aktora i widza, sceny i występu}

Dosyć dawno zauważono, iż istnieje zasadnicza różnica w sposobach docierania do rzeczywistości, które to zasadzały się albo na rekonstrukcji „naoczności wewnętrznej” (idealizm, doskonałość, jedność, przyszłość), albo „naoczności zewnętrznej” (realizm, niedoskonałość, różnorodność, przeszłość). W tym kontekście godne naszej uwagi są badania i analizy poczynione przez Ervinga Goffmana, który zdaje sobie sprawę ze skali trudności posługiwania się pojęciem „rzeczywistość”, a zwłaszcza z tego, że każdy, kto chce ją wyjaśnić i zrozumieć, promować i kształtować, staje przed bardzo trudnym wyzwaniem mającym niewątpliwy wpływ na teraźniejszą i przyszłą jakość naszego życia.

W pewnym sensie autor ten jest wierny maksymie Davida Hume’a, który twierdził, że chociaż nie ma wystarczających dowodów, by przyjąć jakąś obiektywną rzeczywistość, to powinniśmy tak myśleć i działać, jakby faktycznie istniała. Stąd w poszukiwaniu rzeczywistości musimy posługiwać się zarówno faktami, jak i ideami (jest rzeczą charakterystyczną, że współcześni fizycy twierdzą, że nie ma rzeczywistości niezależnej od teorii). Podobne stwierdzenie znajdziemy u Williama Jamesa:

Celem, jaki w rzeczywistości przyświeca naszemu umysłowi, nie jest ani wyłącznie jedność, ani wyłącznie różnorodność, lecz całość. Po temu zaś znajomość zróżnicowań rzeczywistości jest tak samo istotna jak zrozumienie ich więzi (James, 1998, s.117).

Nic dziwnego, że w takiej tradycji myślenia pojawia się projekt Goffmana, dotyczący "pierwotnych ram” rzeczywistości, które mają swoje źródło w faktach określonych „partycypacją widza” lub/i ideach określonych „produkcją aktora".

W związku z tym kluczem do wszystkich zjawisk interakcyjnych jest u niego najprostszy model interpretacji znaków i znaczeń w trybie naturalnym (z pozycji „widza”, na przykład padający deszcz), jak i w trybie społecznym (z pozycji „aktora”, na przykład otwarcie parasola), które mają się tak do siebie, jak rekonstrukcja do konstrukcji. Definiowanie sytuacji interakcyjnych ma podstawę zarówno w rzeczywistości „niczyjej” (przyrodniczej), jak i w rzeczywistości należącej do kogoś. Myślenie i działanie w tych ramach poz- 
wala jednocześnie na odróżnienie wydarzenia symbolicznego od wydarzenia zakorzenionego mimo wszystko $\mathrm{w}$ „twardej rzeczywistości”, a także mechanizmu odróżniania i porównywania oryginału i kopii rzeczywistości ${ }^{8}$.

$\mathrm{Z}$ tego względu trudno byłoby posądzać Goffmana zarówno o pochwałę symulacji i manipulacji subiektywną rzeczywistością, jak i o sugerowanie beznadziejności bezpośredniego docierania do obiektywnej rzeczywistości, w jego wydaniu jest to bowiem zawsze pochwała strukturalnej złożoności (subiektywno-obiektywnej, realno-idealnej), w której wszystkie ludzkie interakcje dzielą się na (1) „produkcyjne” (z pozycji „aktora”) i (2) „partycypacyjne” (z pozycji „widza”).

W pierwszym przypadku zwraca uwagę na kompetencje „animatora” (akustycznego nadawcy wypowiedzi, zarazem ekspresyjnego „emitera”), kompetencje "mocodawcy” (odpowiedzialnego za końcowy komunikat), kompetencje „autora” (komponującego treść wypowiedzi), kompetencje „stratega” (oceniającego komunikat i nadającego mu odpowiedni kierunek) oraz kompetencje „figury” (poddającej się temu, w czyim imieniu się wypowiada, dlaczego i w jaki sposób).

Natomiast „układ partycypacji” obejmuje status, jaki jednostka zajmuje w roli odbiorcy komunikatu, czyli z jednej strony, jest to „status ratyfikowany” obejmujący odbiorców zaadresowanych (lub nie, chociaż mimo to obecnych w procesie komunikacji) i ,status nieratyfikowany” w sytuacji odbioru „przypadkowego" i nieoficjalnego bądź w sytuacji intencjonalnego podsłuchiwania (Goffman, 1981).

Ten dwubiegunowy układ interakcyjny umożliwia, zdaniem Goffmana, analizę ważnego w procesie komunikacji fenomenu "umocowania", przejawiającego się zawsze w trybie oscylacji między „produkowaniem” a "partycypacją", gdzie nie ma ani absolutnego ładu interakcyjnego, ani absolutnego chaosu. W rezultacie określa to nieustanną interakcyjną konstrukcję i rekonstrukcję znaczeń, przypominając fenomen „wielogłosowości” Michaiła Bachtina (1982), akcentujący ograniczoność i wieloznaczność rzeczywistości interakcyjnej, chociaż nie bezradność, bo zawsze z możliwością odwołania się do fenomenu „ram pierwotnych”, dających mniej lub bardziej skuteczne antido-

8 „Odróżniając zaś oryginał od kopii, pozostawiam bez żadnego namysłu kwestię tego, w jaki sposób kopia może zacząć wywierać wpływ na oryginał, jak w sytuacji, gdy film kryminalny podsuwa język i styl prawdziwym przestępcom” (Goffman, 2010, s. 41).

9 Termin „umocowanie” (footing) u tego autora odnosi się jedynie do chwilowego „ustawienia” jednostek wobec innych i wobec siebie, a nie tak, jak chociażby u Herberta Blumera wzajemnego „dopasowania się” partnerów interakcji symbolicznej (Blumer, 2007). 
tum na „truciznę" chaosu interakcyjnego oraz względną odporność na symulację i manipulację jednością lub różnicą.

Fenomen „teatralności” (zwrócony ku makrospołecznemu determinizmowi) Goffman stara się mimo wszystko wyjaśnić w kategoriach skuteczności „ogólnego scenariusza” (mimo że dotąd nie znaleziono zadowalającej analogii między tym, co uniwersalne, a konkretne), zatem „programowo" nie wszystkie zachowania (podmiotów gry) rozstrzyga „rama pierwotna”. Stąd jego analiza tego fenomenu musi wpisać się w pewną „filozofię dramatu”, gdzie niemniej ważne od scenariusza są otwarta scena, gra, reakcje widzów i przeżywany czas.

Właśnie największym odkryciem Goffmana była nie tyle teatralność naszych zachowań, ile fenomen „otwartej sceny”, w której inni są zarazem aktorami i widownią.

Na scenie przedstawia się rzeczywistość udawaną, podczas gdy w życiu przedstawia się przypuszczalnie coś realnego i często improwizowanego. Co może ważniejsze, na scenie aktor występuje wobec innych aktorów jako postać ze sztuki wobec granych przez nich innych postaci; trzecią stronę interakcji tworzy widownia. Widownia ma zasadnicze znaczenie, gdyby jednak to, co dzieje się na scenie, było rzeczywistością, byłaby ona nieobecna. W prawdziwym życiu te trzy strony interakcji zostają zredukowane do dwóch; rola, jaką gra jednostka, jest określona przez innych obecnych, którzy wszakże tworzą zarazem widownię (Goffman, 2000, s. 27).

Dla Goffmana nie tyle jest istotne, „co gramy”, ile jak i gdzie przebiega nasz „występ" ${ }^{10}$. Stąd w takim rozumieniu "gry” nie ma ostrej granicy między występem zawodowego aktora a improwizowanym występem zwykłego uczestnika interakcji - obaj szczerze wierzą, że to, co przedstawiają, odpowiada ich racji stanu. Występ może być prawdziwy lub fałszywy, lecz w każdym przypadku muszą pojawić się warunki wystarczające do wywołania pewnych zdarzeń. Obaj mogą uważać się za tych, za których się podają, mimo że takie pozory mogą być celowo stworzone.

Między przedstawieniem a rzeczywistością istnieje zatem związek statystyczny, a nie przyrodzony czy konieczny. Biorąc pod uwagę nieoczekiwane zagrożenia oddziałujące na przebieg występu oraz konieczność (...) utrzymania przez wykonawcę solidarności z innymi wykonawcami i dystansu wobec publiczności, zauważamy, że niezdolność do oderwania się od własnego poglądu na rzeczywistość może być czasem niebezpieczna dla samego występu. Niektóre z nich kończą się sukcesem, choć są całkowicie nieuczciwe, inne - ponieważ są do końca uczciwe, lecz ani uczciwość, ani nieuczciwość nie są w przedstawieniu najistotniejsze. Być może, nie są nawet dramaturgicznie pożądane (Goffman, 2000, s. 100).

10 „Występ» (performance) można zdefiniować jako wszelką działalność danego uczestnika interakcji w danej sytuacji służącą wpływaniu w jakiś sposób na któregokolwiek z innych jej uczestników” (Goffman, 2000, s. 45). 
Goffman $w$ tym ostatnim zdaniu chce nam $\mathrm{z}$ jednej strony powiedzieć, iż nasze zamiary wcale nie wiążą nas silniej ze światem rzeczywistym, a to, co czasami może uchodzić za „improwizację, tak naprawdę jest precyzyjnym scenariuszem odgrywanym wielokrotnie, czasami również wykorzystując zjawisko „socjalizacji antycypującej”, czyli umiejętności odtwórczego lub twórczego przewidywania rzeczywistości. To, co było jedynie możliwością, staje się $\mathrm{w}$ pewnym momencie rzeczywistością interakcyjnie zaktualizowaną. Z kolei nawet $\mathrm{w}$ najdokładniejszym scenariuszu nie znajdziemy takich szczegółów, które uwolniłyby nas od uważnego śledzenia reakcji widowni, koncentracji na formie komunikatu czy namysłu nad ewolucją wywoływanego wrażenia.

Na ogół przygotowujemy tylko pewną liczbę „dramaturgicznych chwytów”, którymi wypełniamy określoną rolę. Fakt, że zagraliśmy skutecznie, wcale nie przekłada się na naszą wiedzę: „jak grać skutecznie”. Status gracza nie jest czymś materialnym, co można nabyć i pokazywać wielokrotnie.

Autentyczne występy w życiu codziennym nie są "grane” czy „wystawiane” w tym sensie, że ich wykonawca wie z góry, co będzie robił, i robi to jedynie ze względu na efekt, jaki chce uzyskać. Wrażenie, jakie czuje, że wywiera, jest mu w jakimś sensie niedostępne. (...) Krótko mówiąc, wszyscy lepiej gramy, niż wiemy, jak mamy grać (Goffman, 2000, s. 102).

W odróżnieniu od gry zawodowych aktorów podstawą skutecznej gry w życiu codziennym staje się informacja o pozostałych jej uczestnikach, dotycząca tego, co można oczekiwać od innych, i czego inni oczekują od nas. Dzięki tej informacji dowiemy się, jak ma przebiegać nasz występ, by uzyskać najbardziej pożądane wrażenie, a w zasadzie, jak zauważa Goffman, dwa różne wrażenia, które przekazujemy (gives) i wywołujemy (gives off). Ta podwójność wrażeń, praktycznie na scenie nie do odróżnienia, nie przeszkadza, jeśli występ kończy się sukcesem, w przeciwnym razie różnica może okazać się bardzo bolesna. Udany występ nie daje jednak pewności, że wywołane wrażenia są tymi zamierzonymi, widz może bowiem reagować tak, jakby był pod tym właśnie wrażeniem, a w rzeczywistości działa w sposób głęboko wyrachowany.

W związku z taką nieprzejrzystością sytuacji możemy podzielić wrażenia na te, które dają się stosunkowo łatwo kontrolować i te, które są bardzo odporne na wszelkie manipulacje.

W tym ujawnia się podstawowa asymetria procesu komunikacyjnego; jednostka działająca przypuszczalnie jest świadoma tylko jednego aspektu swojego komunikowania się z innymi, podczas gdy obserwatorzy są świadomi obu (...). Właśnie świadoma kontrola nad odgrywaną przez aktora rolą, w pewnym stopniu przywraca symetrię procesowi komunikacji i tworzy scenę dla swego rodzaju gry informacyjnej - potencjalnie niekończącego się cyklu ukrywania i odkrywania, fałszywych objawień i ponownych odkryć (Goffman, 2000, s. 37-38). 
Mówiąc inaczej, kontrola obejmuje nie to, co spontaniczne, ale to, co poddaje się manipulacji rzekomo spontanicznymi elementami zachowania (umożliwia granie spontaniczności), podtrzymując jakoby rzeczywistą asymetrię w procesie komunikacji. Wykrycie tego pozoru przez współuczestników gry może z kolei skutkować pozorną spontanicznością reakcji. W ten sposób co prawda osiąga się pewien interakcyjny modus vivendi, w którym wszyscy mają świadomość nie tyle rzeczywistego stanu rzeczy, ile rzeczywistego konsensu, co do statusu roszczeń i unikania otwartego konfliktu. Jeśli w takim przypadku osiąga się tylko doraźną zgodę narzuconą definicją sytuacji, to na tyle stabilną, że możemy mówić tu o określonej roli.

Można oczywiście domniemywać, że na ową rolę składa się dużo więcej czynników, wśród których Goffman wymienia między innymi „fasadę” (dekorację, powierzchowność), czyli grę w stałych i zmiennych „dekoracjach społecznych”, które służą zarówno do wzmocnienia pożądanego wrażenia, jak i kontroli procesu przywracania symetrii komunikacyjnej. Przede wszystkim „fasada” ma podnieść stopień dramatyzacji zachowań, czasami tylko po to, by zrobić „dobre wrażenie” (szczególnie, gdy jest to pierwsze wrażenie), czasami by skuteczniej coś zakomunikować. Niebezpieczeństwem fasadowości jest nadmierne skupienie się na tym, co nieistotne, formalne, powierzchowne, a nawet banalne.

Dobre odegranie swojej roli wymaga także, zdaniem Goffmana, swego rodzaju „spójności ekspresyjnej”, czyli mniej lub bardziej świadomego panowania nad stopniem zbieżności (bądź rozbieżności) między Ja indywidualnym, a Ja uspołecznionym ${ }^{11}$. Mówiąc inaczej, tożsamość Ja nie jest czymś stałym i samowystarczalnym, lecz jest „efektem scenicznym”, który tworzy przedstawienie, dzięki temu, że aktorzy-widzowie czynią podmiot występu przedmio-

11 „W społeczeństwie naszym między «ja» wykonawcy a odgrywaną postacią stawia się niemal znak równości i w tym «ja», czyli postaci-którą-się-gra, widzi się coś, co zamieszkuje ciało swego posiadacza, zwłaszcza jego górne partie, zamknięte jakoś w ramach psychobiologii osobowości. Jestem skłonny twierdzić, że pogląd ten wyraża w jakimś stopniu to, co wszyscy staramy się zaprezentować, ale - z tego właśnie powodu - stanowi bardzo złą analizę zjawiska prezentacji. W tej pracy «ja» przedstawiane na scenie było traktowane jako swego rodzaju obraz własnej osoby, na ogół pochlebny, który jednostka grająca określoną postać stara się skutecznie wywołać u innych. Chociaż ten obraz dotyczy jednostki, a określone «ja» jej właśnie jest przypisywane, to samo «ja» kształtuje nie jednostka, do której owo «ja» przynależy, lecz cała sceneria jej działalności, ponieważ «ja» tworzy się dzięki temu, że świadkowie czynią jednostkę przedmiotem interpretacji. Właściwie wystawiona i odegrana scena powoduje, że publiczność przypisuje jakieś «ja» przedstawionej postaci, ale to przypisanie jest rezultatem zaprezentowanej sceny, a nie jej przyczyną. Tak więc «ja» jako odgrywana postać nie jest czymś organicznym, umiejscowionym w określony sposób, czymś, czego przeznaczeniem są narodziny, dojrzałość i śmierć; jest efektem scenicznym, który rodzi przedstawiona scena, sprawą zaś podstawową i najbardziej charakterystyczną jest to, czy efekt ten będzie dla publiczności przekonujący, czy też podany w wątpliwość” (Goffman, 2000, s. 277). 
tem interpretacji. Stąd „spójność ekspresyjna” wymaga znacznego usztywnienia środków wyrazu, a jednocześnie strategicznego rozmieszczenia pewnych obszarów niedomówień, które pozwolą na względne zachowanie jakiegoś status quo w stosunkach aktor-widownia (jednostka-inni).

W każdym razie taka sytuacja czyni nasze zachowania bardziej realnymi, a co najważniejsze nie zmusza nas bezwzględnie do konsekwentnego ujednolicenia wszystkich sfer naszej działalności, tworząc obszary jedności i różnicy. Dlatego Goffman nie przywiązuje wielkiej wagi do rozgraniczenia między „byciem sobą" a "udawaniem innego", istotne jest tu strukturalne miejsce szczerości $w$ dramacie wydarzeń, oznaczające stopień przekonania siebie i widza co do intencji i motywów występu.

A dzieje się tak dlatego, że naturalne stosunki społeczne powstają w taki sam sposób, w jaki powstaje sytuacja na scenie: przez wymianę dramaturgicznie uwznioślonych działań, reakcji na działania i zamykających kolejne sceny odpowiedzi. Scenariusz nawet w ręku niewprawnego aktora może ożyć dlatego, że samo życie ma konstrukcję dramatyczną. Oczywiście, nie cały świat jest sceną, lecz niełatwo rozstrzygnąć, w jakiej mierze sceną nie jest (Goffman, 2000, s. 100).

Zatem socjalizacja nie polega na wyuczeniu się mnóstwa szczegółowych zachowań wynikających z określonej roli (na wszystkie nie starczyłoby ani czasu, ani energii), ale na wyuczeniu się określonej liczby „niezawodnych chwytów” wystarczających do jej efektywnego (rzadziej w pełni skutecznego) wypełnienia i orientacji w scenie, zwłaszcza w jej newralgicznych punktach i istotnych środkach wyrazu, które mogą przypaść w udziale.

Oczywiście ten rodzaj oczekiwania inaczej przedstawia się, gdy partnerzy (uczestnicy gry) będą z sobą współpracować (kooperacja pozytywna) na przykład w podtrzymaniu względnie jednolitej definicji sytuacji, a inaczej, gdy będą rywalizować (kooperacja negatywna) na przykład w destrukcji występu przeciwnika. Nawiasem mówiąc, w takiej grze nie ma większego znaczenia, czy związek łączący uczestników gry ma charakter formalny czy nieformalny, rzeczywisty związek sceniczny ma miejsce wtedy, gdy określone jednostki w sposób uzgodniony explicite lub implicite przedstawiają działania w określonym świetle, w określonej sekwencji interakcji, dzięki którym utrzymywana jest stosowna definicja sytuacji (sceny). 


\section{Rama naturalna i rama społeczna}

W rozumieniu słownikowym termin „rama” oznacza „ograniczony zakres czegos”, a określenie „ramowy” odnosi się do „ogólnego schematu”, „zarysu bez szczegółów”. W literaturze naukowej dużym powodzeniem cieszy się pojęcie „ramy” jako „schematu poznawczego” lub „mentalnej struktury” znaków i znaczeń kształtujących nasz sposób patrzenia na siebie i innych, gdzie każde „obramowanie” oznacza pewne ustabilizowanie obszaru tego widzenia, a każde „przeramowanie” (reframe) wiąże się ze zmianą jakościową tego widzenia. Czasami pojęcie „ramy” łączy się z organizacją zasad definiujących określone sytuacje społeczne bądź z konstruowaniem fundamentalnych schematów interpretacji codziennych interakcji, jak właśnie ma to miejsce w przypadku Goffmana.

Niezależnie od sposobu definiowania „ramy” możemy zauważyć, iż każda nasza wypowiedź jest interpretowana w zakresie tego, co najbardziej pamiętamy, co najczęściej widzimy i słyszymy, co najsilniej przeżywamy i pragniemy. A najgorsze w tym przypadku, jak twierdzi Goffman, jest to, iż „w większości «sytuacji» wiele rzeczy dzieje się równocześnie" (Goffman, 2010, s. 10). Ponadto rzadko zdajemy sobie sprawę z tego, iż:

Dowolne wydarzenie można opisać, zakładając szerokie lub wąskie pole widzenia, a także - rzecz powiązana, lecz nie tożsama - zakładając perspektywę bliską lub z oddali. Nikt nie dysponuje teorią wyjaśniającą, dlaczego zastosował konkretny zakres lub poziom rozważań (Goffman, 2010, s. 10).

Zdaniem tego autora efektywną interpretację może zapewnić jedynie „klarowność ramy” ${ }^{12}$, natomiast jej zmętnienie zmusza jej właściciela zarówno do (re)konstrukcyjnego „oczyszczenia”, jak i dekonstrukcyjnego rozbicia.

Niezależnie jednak od stopnia organizacji, każda rama pierwotna pozwala jej użytkownikowi na umiejscowienie, dostrzeżenie, identyfikację i nazwanie pozornie nieskończonej liczby konkretnych wydarzeń zdefiniowanych w jej kategoriach (Goffman, 2010, s. 257).

Cytowany autor wyróżnia dwa rodzaje ram pierwotnych: ramy naturalne i ramy społeczne. To, co je różni, odnosi się do rozpatrywania konkret-

12 „Przez termin «rama klarowna» (clear frame) będę odnosić do takiego porozumienia, jakie ma miejsce, gdy wszyscy uczestniczący danej czynności posiadają klarowny stosunek do ramy; będę tu podejmował próbę przeprowadzenia rozróżnienia między wyjaśnieniem własnego stosunku do ramy a uczestnictwem w ramie, która jest klarowna, to znaczy klarowna dla wszystkich uczestników. Stwierdzić, że jakaś rama jest klarowna, to nie tylko stwierdzić, że każdy uczestnik posiada nadający się do zastosowania, poprawny ogląd tego, co się dzieje, lecz także znośnie poprawny ogląd oglądów innych osób, co obejmuje ich ogląd jego oglądu” (Goffman, 2010, s. 257). 
nych wydarzeń w perspektywie działania intencjonalnego lub pozbawionego jakiegokolwiek świadomego zamiaru, zamysłu i celu. Zasadniczą różnicą między ramami naturalnymi i społecznymi jest rola przypisywana "aktorom i widzom”. W przypadku perspektywy naturalnej jednostka ma status „widza” (partycypującego obserwatora), będąc podatna temu samemu deterministycznemu, nieświadomemu, niemoralnemu (nonmoral) sposobowi bycia, jaki dotyczy każdej innej części sceny. Natomiast zupełnie inna jest pozycja jednostek w ramach społecznych, które są definiowane jako „samookreślające się podmioty", posiadające kompetencje do działania oraz moralnego odpowiadania za to, by działać poprawnie, jednym słowem, by jak najlepiej zagrać swoją rolę „aktora” (producenta zdarzeń).

Ramy naturalne identyfikują wydarzenia postrzegane jako „niczyje”, nieukierunkowane, niekontrolowane, „czysto fizyczne”, jako całkowicie, od początku do końca, zdeterminowane przez czynniki niezależne od naszej intencji. $\mathrm{W}$ ich perspektywie przyjmuje się, że w określonej sytuacji nie ma miejsca żadna interwencja przyczynowa czy celowa, że żaden „aktor” nie steruje wynikiem w sposób stały. Nie można też mówić tutaj ani o sukcesie, ani o porażce, jak również nie wiążą się z nimi żadne sankcje negatywne czy pozytywne. Jednym słowem, ramy naturalne wspierają się na pytaniu: za pośrednictwem czego coś zaistniało (lub nie)? Tym samym określają obiekty „naturalne”, nienależące do doświadczenia kogoś. Mówiąc inaczej, są to obiekty pozostające poza człowiekiem, jako ich sprawcą, na przykład przejawiające się w komunikacie: „spada temperatura powietrza”, „rośnie zachmurzenie”, „pada deszcz" itd., która to wypowiedź formowana jest zdecydowanie z pozycji „widza”.

Natomiast ramy społeczne dostarczają podstawowego zrozumienia wydarzeń „czyiś”, na które składają się wola, zamysł i kontrolujący wysiłek intelektu, a także ożywiona sprawczość istoty ludzkiej. Taki czynnik sprawczy nie jest konieczny i można nim kierować, sterować lub manipulować. Działania te powodują, że sprawca podlega „standardom”, a jego aktywność jest przedmiotem społecznej kontroli i oceny pod kątem jej uczciwości, skuteczności, oszczędności, bezpieczeństwa, elegancji, taktowności, dobrego smaku itd. Tutaj stale sprawuje się nadzór nad konsekwencjami, które stają się najbardziej widoczne wówczas, gdy czynność zostaje nieoczekiwanie zablokowana i niezbędny jest szczególny wysiłek kompensacyjny.

Ramy społeczne, w przeciwieństwie do poprzednich, wyjaśniają wydarzenie poprzez motyw, zamiar lub cel, który je wywołał, zatem pytają się: co trzeba zrobić (lub nie) dla osiągnięcia czegoś?, czyli określają obiekt naszej woli sprawstwa lub tego, co zostało zrobione zgodnie z czyjąś intencją, dopuszczając dwa typy interpretacji: (1) dotyczącej materialnego śledzenia i kontrolowania środ- 
ka komunikacji (fizycznego nośnika znaku i znaczenia) oraz (2) dotyczącej kontekstowego emitowania i odbierania znaków, znaczeń oraz reguł ich stosowania. Są to wydarzenia przejawiające się w komunikacie: „nie odpowiada mi taka temperatura”, „brak słońca nie popsuje nam spaceru”, „mimo że nie pada deszcz i tak zabierzmy parasol" itd., w tej ramie jesteśmy przede wszystkim „aktorem”, który podejmuje się działania w imię pewnego dobra, którego może być współudziałowcem.

\section{Rola aktora-widza w analizie ramowej}

Bardzo słusznie zauważa Goffman, że nie jest łatwo oddzielić intencje od naturalnych środków użytych do ich aktualizacji, jednym słowem intencję „aktora” od oczekiwań „widza”'13, bowiem:

(...) wszystko, co sprawca usiłuje uczynić, będzie stale warunkowane przez ograniczenia naturalne, zaś skuteczne działanie będzie wymagać wykorzystania tego stanu rzeczy, a nie jego pominięcia. (...) Zakłada się zatem, że choć wydarzenia naturalne mają miejsce bez rozumnej interwencji, rozumnych działań nie da się skutecznie przeprowadzić bez wkroczenia w porządek naturalny. Każda sekwencja społecznie kierowanego działania może zostać częściowo przeanalizowana w obrębie schematu naturalnego (Goffman, 2010, s. 22-23).

W takim ujęciu przestrzeń ludzkich interakcji staje się raczej jakąś formą rzeczywistej gry (gry na serio, gry jako gry, metagry), nie tyle w konwencji tradycyjnego teatru $\mathrm{z}$ wyraźnym podziałem na aktorów i widzów, jak sugeruje Goffman, ile w konwencji swoistego rodzaju „teatru eksperymentalnego”, ze swoją rozproszoną sceną i dynamicznym scenariuszem, gdzie nie tylko, że nie ma stałego podziału na aktorów i widzów, którzy abstrahują od całości widowiska, ale każdy ma swoją rolę ${ }^{14}$. Widz może w każdej chwili stać się bardziej

13 Aktor oczekuje przede wszystkim skutecznego osiągnięcia zamierzonego celu na podstawie analizy dostępnych mu przesłanek (znajomości sposobów oddziaływania na rzeczywistość, znajomości przyczyn i skutków, pod kątem tego, w jakim stopniu gwarantują one rozwiązanie planowanego zadania). Widz z centrum swoich zainteresowań wyklucza własne hipotezy, czy przesłanki działań, a cały proces rozumowania skupia nie na tym, jaka jest racja wystąpienia określonego zdarzenia, ale czym jest samo to zdarzenie. W ten sposób rozumowanie aktora można opisać jako przechodzenie od subiektywnych racji do obiektywnej wiedzy o ich następstwach, a rozumowanie widza jako przechodzenie od obserwowanych obiektywnych następstw do subiektywnej wiedzy o racjach ich zaistnienia. Mówiąc inaczej, aktora interesują przede wszystkim warunki i środki potrzebne do wywołania określonego zdarzenia, widza - przyczyny, które je wywołują. Aktor jest bardziej praktykiem, widz bardziej teoretykiem.

14 Nawiasem mówiąc, nie wiem, dlaczego widza postrzegamy zawsze biernie, natomiast aktora czynnie, wprawdzie w samym słowie „aktor” wyraźnie słyszy się „akt” (czyn, działanie), lecz widz także w jakimś stopniu aktualizuje swoją rolę, tzn. mniej lub bardziej aktywnie obserwuje, 
aktorem, a aktor bardziej widzem, w każdej sytuacji w różnych proporcjach i różnych relacjach jakiś aktor staje się zarazem widzem i odwrotnie (Gadamer, 2004, s. 158-199). Tam, gdzie widz świadomie staje się aktorem, a aktor widzem, widowisko nie redukuje się do statycznej recepcji (nadawania i odbierania znaków i znaczeń), lecz staje się wieloznaczne także w swojej percepcji i recepcji interakcyjnej, gdzie obok znaków-słów taką samą rolę zaczynają odgrywać znaki-obrazy, znaki-sygnały, znaki-symbole. Aktor tak samo jak widz, a widz tak samo jak aktor musi na nowo rozpoznać i zrozumieć znaki, znaczenia i reguły gry, by sprostać logice antycypowanej ewolucji i paralogii zaskakujących zmian.

Ma tego w pewnym stopniu świadomość także Goffman, który wprowadza szereg odrębnych kwestii mających wpływ na nasze „całościowe rozumienie funkcjonowania” ram pierwotnych. Jest to dla niego przede wszystkim „kompleks zdziwienia", gdy brakuje prostego i naturalnego wytłumaczenia wydarzenia; „zainteresowanie kosmologiczne”, gdy obserwujemy coś pozornie niemożliwego; „sytuacja potknięcia”, gdy obiekt uznany za działanie kierowane intencjonalnie, nieoczekiwanie wymyka się spod kontroli; „kwestia przypadkowości", gdy mamy przeświadczenie o nadzwyczajnym zbiegu okoliczności; "zagadnienie oddzielenia”, gdy mamy zasadniczą trudność w swobodnym przemieszczeniu się między interpretacją odwołującą się do natury i do kultury (Goffman, 2010, s. 26-33).

\section{Transpozycje i fabrykacje ramy pierwotnej}

Zdaniem Goffmana, wszelkie przekształcenia ramy pierwotnej wykorzystują tak zwany mechanizm „klucza” (analogicznie jak w zapisie nutowym melodii odgrywa rolę klucz wiolinowy i basowy), który według niego oznacza: „Zbiór konwencji, poprzez które dana czynność, już znacząca w obrębie jakiejś ramy pierwotnej, jest przekształcana w coś wzorowanego na tej czynności, lecz postrzegana przez uczestników jako coś zupełnie innego" (Goffman, 2010, s. 37).

interpretuje, kontroluje, ocenia i wyraża swoją aprobatę lub dezaprobatę, tym samym widz w jakimś zakresie jest także aktorem, a to oznacza, że nikt nie działa obok siebie, w imieniu kogoś lub za kogoś. Również aktor nie jest pozbawiony całkowicie możliwości obserwowania. W związku z tym zarówno „aktor-widz”, tak samo jak „widz-aktor” coś „aktualizuje”, „urealnia”, „czyni” widocznym, to, co było tylko możliwe. W każdym akcie zaś może być zawarowane poczucie odpowiedzialności „za” (np. za posunięcie w grze, za wynik gry, za innych graczy, za widzów), odpowiedzialności „w” (np. w określonej sytuacji nie możemy lub możemy się wycofać bądź wziąć coś na siebie, bądź też scedować coś na innych), odpowiedzialności „na” (np. ciążącej na sprawcy określonego czynu, roli, postaci). 
Ten swoisty proces transkrypcji tego, co pierwotne i wtórne lub odwrotnie, autor nazwa "kluczowaniem” (keying), czyli działaniem według klucza lub „przykładaniem” klucza, który określone działanie realne, pozostające w ramie pierwotnej, przekształca w działanie symboliczne bądź działanie symboliczne (z określonej lektury lub filmu) może być przełożone na realne działanie tu i teraz.

Egzemplifikacją takiego sposobu „przykładania klucza” do ramy pierwotnej są: (1) „zmyślenia”, (2) „zawody”, (3) „ceremonie”, (4) „próby techniczne” oraz (5) „powtórne założenia”. Z myślenia, z jednej strony, mają na celu prowokowanie zabawy, czyli wywołanie aktywności dającej jakąś przyjemność, dobry humor, rozrywkę, relaks itd., z drugiej strony mają za przedmiot wszelki rodzaj fantazjowania, „snu na jawie”, wynikający z marzeń oraz pragnień. Mogą też wchodzić tutaj w rachubę różne próby tworzenia symbolicznych inscenizacji i scenariuszy teatralnych, filmowych czy widowiskowych itd. Zawody dotyczą najczęściej rywalizacji sportowej z wykorzystaniem (lub nie) określonych chwytów scenicznych w ramach zasad fair play. C e rem o nie obejmują niemal wszystkie znaczące rytuały społeczne (urodziny, śluby, pogrzeby, nadawanie stopni i tytułów itd.). Próby techniczne opierają się zarówno na abstrakcyjnych ćwiczeniach operacyjnych i czynnościowych, jak i na wszelkich demonstracjach (także medialnych) i symulacjach rzeczy, osób i zdarzeń, w tym również mniej lub bardziej uporządkowanych eksperymentach. Powtórne założenia, zdaniem Goffmana, zasadniczo różnią się swoim charakterem od powyższych prób przekształcania ramy pierwotnej i są najbardziej kłopotliwe.

Chodzi tu o mniej lub bardziej otwarte wykonywanie jakiejś czynności z powodów czy motywów odczuwanych jako radykalnie różne od tych, jakie rządzą zwykłymi aktorami. Pojęcie powtórnych założeń opiera się na przekonaniu, że niektóre motywy czynu pozostawiają jego wykonawcę w normalnym kręgu uczestnictwa, inne motywy zaś - zwłaszcza kiedy ulegają stabilizacji oraz instytucjonalizacji - stawiają wykonawcę poza zwykłym obszarem działania (Goffman, 2010, s. 60).

Istnienie ramy, która zawiera ponowne transpozycje, wraz z każdym przetworzeniem dodającym „warstwę” lub „laminację” (lamination) do danej czynności, zawiera dwie cechy.

Pierwsza to najgłębsze uwarstwienie, gdzie może chodzić o czynność dramatyczną, która wszechogarnia uczestnika. Inna to laminacja najbardziej zewnętrzna, jak gdyby krawędź (rim) ramy, która mówi nam, jaki status dana czynność posiada w świecie rzeczywistym, niezależnie od złożoności warstw wewnętrznych (Goffman, 2010, s. 66).

Abstrahując jednak od zróżnicowania wewnętrznego lub zewnętrznego, przykładanie klucza (transpozycja) dostarcza nam jednego podstawowego sposobu, w jaki określony wycinek czynności może zostać przekształco- 
ny, a zatem punkt po punkcie może posłużyć jako model dla czegoś innego. Mówiąc inaczej, przykładanie klucza ukazuje w istotny sposób podatności na przekształcenia czynności. Co oznacza, że mogą funkcjonować również inne przykłady takiej podatności, na przykład mistyfikacje. Przykładanie klucza w zasadzie nie burzy naszej świadomości, że ramy pierwotne są bardziej prawdziwe od tych przekształconych, zatem tworzy to pewne kontinuum od tego, co pierwotne, do tego, co wtórne, po drodze ujawniając różne „nawarstwienia” zdarzeń. Mimo wszystko w transpozycji pierwotna rama zmusza nas ciągle do redefinicji danej sytuacji, nawet najbardziej skomplikowanej i wieloznacznej. Dopiero radykalny sposób celowego zafałszowania zastanej rzeczywistości, zwany przez Goffmana „fabrykacją”, przecina to kontinuum.

„Fabrykacja” to, zdaniem tego autora: „celowy wysiłek jednej lub więcej osób, by tak pokierować czynnością, że druga strona, składająca się z jednej lub więcej innych osób, przyjmuje fałszywy ogląd tego, co się dzieje" (Goffman, 2010, s. 67). „Sfabrykowany” w ten sposób ogląd rzeczywistości daje odbiorcy komunikatu wrażenie, iż „coš” lub „ktoš” jest czymś lub kimś innym, niż obiektywnie rzecz biorąc. W tym przypadku celowo przykrywa się ramę pierwotną ramą sfabrykowaną. Przy czym Goffman wyróżnia „fabrykacje życzliwe” i „fabrykacje eksploatacyjne”. Te pierwsze, zasadniczo pozostając nieszkodliwymi dla tych, którzy są przez nie „pochwyceni”, te drugie na ogół wywołują sankcje prawne i karne. Fabrykacje życzliwe autor dzieli z kolei na: (1) „zabawowe oszustwa”, (2) „mistyfikacje eksperymentalne”, (3) „mistyfikacje treningowe”, (4) „testy krytyczne”, (5) „konstrukcje paternalistyczne” oraz (6) „fabrykacje strategiczne”.

Zabawne oszustwo zniekształca ramę pierwotną, ale długofalowo nie narusza interesu osoby lub osób wprowadzonych w błąd. Jest to jakaś forma tak zwanego „kawału”, „psikusa”, „wkręcenia” podmiotu w rolę, której nie jest świadomy i która prędzej czy później zostaje przez niego odkryta, a cała mistyfikacja często okazuje się lepszym lub gorszym żartem i źródłem rozrywki dla wtajemniczonych i bywa też, że również dla „wkręconych”. Mistyfikacje eksperymentaln e zasadniczo wykorzystują niewiedzę poddawanych czynnikowi eksperymentalnemu (by sprawdzić ich rzeczywiste zdolności, potrzeby lub motywy) i dopiero pod koniec „obserwacji projektującej” wyjaśniane są cele i skutki tej fabrykacji. Mistyfikacje treningowe angażują osoby $\mathrm{w}$ pozornie naturalną sytuację, a w rzeczywistości jest to działanie niemal w całości kontrolowane. Testy krytyczne są po prostu formą kontrolowanego przecieku informacji. Konstrukcje paternalistyczne są takim rodzajem fabrykacji ramy pierwotnej, która tworzy wrażenie, iż wszystko dzieje się w interesie oszukiwanego. Fabrykacje strategiczne dotyczą szczegól- 
nego rodzaju mistyfikacji, która ma na celu monitorowanie jakości pracy osoby poddanej procesowi fabrykacji ramy.

Wymienione wyżej fabrykacje ramy pierwotnej zazwyczaj są chwilową mistyfikacją, która zostaje odkryta przez oszukiwanego lub przez „wkręcających”, natomiast drugi rodzaj wprowadzenia osób w błąd, który Goffman nazywa „fabrykacjami eksploatacyjnymi”, ma trwale prowadzić osoby do utożsamienia się z ramą fałszywą. Jest to o tyle łatwiejsze, o ile poddani fabrykacji charakteryzują się dużą dozą ignorancji, brakiem wyobraźni i wiedzy, „dziecinną naiwnością", łatwowiernością co do wartości działania pozorowanego itp. W przeciwieństwie do „fabrykacji życzliwych” te o charakterze eksploatacyjnym mogą w większości przypadków pociągać za sobą określone środki prawne i karne.

Goffman, pokazując w zasadzie dwa sposoby, na jakie można pozbawiać jednostkę kontaktu z tym, co się naprawdę dzieje, czyli oszustw życzliwych i oszustw w celu wyzyskania („wrobienia” dla korzyści materialnych lub mentalnych osób fabrykujących ramę), dokłada do tego pakietu fabrykacji rzeczywistości jeszcze samooszukiwanie się (Goffman, 2010, s. 88). Wszystkie zaś razem są społecznie powszechne, ponieważ - jak sądzi ten autor - wynikają one z uniwersalnej skłonności człowieka do upraszczania (idealizacji) tego, co złożone i wieloznaczne. Swoiste pragnienie jedności u ludzi, wzmocnione dążeniem do jak największej „ekonomii myślenia i działania” (skuteczności, efektywności, wydajności, oszczędności), wprowadza ich w ramiona gotowego schematu, który jednocześnie eliminuje subtelne i wielowymiarowe analizy określonego wydarzenia i, co najważniejsze, uwalnia ich od ryzyka i wysiłku nie tylko czasochłonnej i energochłonnej, ale przede wszystkim wszechstronnej analizy ramowej (od strony aktora i od strony widza), prowadzącej do ciągłego „obramowania”, „przeramowania” lub „wyklarowania ramy”. Nie mówiąc już o postawie przygotowanej na „rozbicie ramy”.

To ostatnie wymaga jednak, jak stwierdza Goffman, odważnego i odpowiedzialnego „wyjścia z siebie”, transgresji i prospekcji, które to może być „doświadczeniem pozytywnym”, gdy „oczyszczamy ramę pierwotną” z wtórnych nawarstwień, i „doświadczeniem negatywnym”, gdy „rozbijamy ramę”, nie mogąc dłużej tłumić oporu wobec przyjętego symbolicznego porządku gry lub totalnego zafałszowania rzeczywistości, bądź, co gorsze, wobec pojawienia się „Czynności pozaramowych” w postaci przemocy i agresji. 


\section{Rozbicie ramy i wytwarzanie doświadczenia negatywnego}

Dotychczasowe analizy koncepcji E. Goffmana pokazywały jednostkę jako kogoś, kto posiada ogląd zgodny z ramą lub ogląd fałszywy i podejmuje zarówno jakieś działanie symboliczne, jak i materialne na podstawie tego oglądu. A zatem każde „ramowanie wydarzeń” przez jednostkę ustanawia dla niej ich znaczenie, a także organizuje w nich jej zaangażowanie. Zatem, jak stwierdza ten autor: „Wszystkie ramy obejmują oczekiwania rodzaju normatywnego w kwestii tego, jak głęboko i dalece jednostka ma zostać poniesiona w czynności organizowanej przez te ramy" (Goffman, 2010, s. 263).

Oczywiście, ramy różnią się dość wyraźnie pod względem stopnia zaangażowania zalecanego utrzymującym je uczestnikom. We wszystkich jednak przypadkach są ustanowione pewne granice (definicje) tego, co jest zaangażowaniem niewystarczającym, a co zbyt wielkim w określonej sytuacji. Zaangażowanie lub wciągnięcie (się) w wir wydarzeń nie zawsze oznacza działanie całkowicie świadome, dlatego zasadniczo poprawne rozpoznanie danej sytuacji często jest niewystarczające. Mówiąc inaczej, zawsze może się coś wydarzyć, z czym sobie nie poradzimy, jakieś nieprzewidywane okoliczności, do których nie da się zastosować danej ramy, co skutkuje załamaniem jej stosowalności lub całkowitym jej rozbiciem.

Zdaniem Goffmana jednym z największych udziałowców w procesie rozbicia ramy jest nasz naturalny organizm psychofizyczny, a szczególnie pewna jego część, czyli wyraz naszej twarzy skutkujący wybuchem śmiechu, płaczu, gniewu, sygnalizujący w pewien sposób „wyjście z siebie” (flood out). Dzieje się tak czasami, dlatego że jednostka zmuszona została do odegrania roli, którą uważała za istotnie niezgodną z samą sobą i próbując zachować „pozory normalności”, gromadzi „niechcianą energię” aż do erupcji. Inną przyczyną rozbicia ramy może być zbyt precyzyjny scenariusz odgrywanej sceny, który nie przewiduje alternatywnego rozwoju zdarzeń, i w tej sytuacji wystarczy jedno zauważone przez większość uczestników nieformalne zdarzenie, by spektakl nabrał groteskowego wymiaru i potoczył się w zupełnie innym kierunku.

Gdy z dowolnego powodu jednostka rozbija ramę i dostrzega, że to uczyniła, natura jej pochłonięcia oraz przekonań nagle się zmienia. Zastrzeżenia, jakie miała pod adresem bieżącej czynności, zostają nagle przerwane i, przynajmniej chwilowo, będzie ona zapewne intensywnie zajmować się swymi tarapatami; daje się bez zastrzeżeń pochłonąć zarówno swej niezdolności do utrzymania stosownego zachowania, jak i przyczynie tej niezdolności. Jednostka traci, przynajmniej chwilowo, cały dystans i rezerwę, jakie mogła utrzymywać wobec uprzednich wydarzeń, razem z tą świadomą kontrolą, jaką mogła sprawować nad tym, co się działo. Zostaje natychmiast wrzucona w swe tarapaty bez zwykłych środków obronnych. Oczekując zajęcia pozycji w dobrze ramowanej rzeczywistości, odkrywa, że żadna konkretna rama nie da się od razu zastosować lub że rama, o której sądziła, że da się zastosować, już się 
nie wydaje stosowna, lub też nie może się odnaleźć w ramie, jaką najwyraźniej się stosuje. Traci władzę nad formułowaniem reakcji, która byłaby wykonalna (Goffman, 2010, s. 287).

Jeśli jednostka doświadcza kogoś lub czegoś, kim nie była (lub w czym nie była), to jest to, zdaniem Goffmana, „doświadczenie negatywne”. Przy czym autor wyróżnia przy jego pojawieniu się celowy i niecelowy udział innych. Ten pierwszy ma miejsce w spotkaniach „twarzą w twarz” poprzez akty słowne na przykład wyśmiewania lub akty fizycznego dokuczania, wytrącające ich odbiorcę z możliwości samokontroli. Może być to także szczególny typ „stresującej perswazji", zwłaszcza w sytuacji, gdy nie pojawia się pewien rodzaj napięcia (odbiorca-nadawca) i komunikat pozostaje jednokierunkowy i monodramatyczny. Gdzie nie tyle chodzi o merytoryczne przekazanie informacji, ile o danie pewnego „dramatycznego przedstawienia”, które odgórnie konstruuje rzeczywistość.

W związku z tym wiele miejsca Goffman poświęca analizie ramowej samego fenomenu „rozmowy” jako szczególnego typu interakcji prowadzącej do jakiegoś wyjaśnienia czy rzadziej porozumienia, w czym jesteśmy podobni, a w czym się różnimy.

Rozmowa jawi się jako szybko zmieniający się strumień rozmaicie ramowanych wycinków, obejmujący krótkotrwałe fabrykacje (zazwyczaj życzliwe) oraz różnego rodzaju transpozycje. Występują tu wskazówki co do przekształceń, określające szczegółowo, czy należy zastosować jakąś wersję tego, co typowe, a jeśli tak, to jakiego rodzaju odmianę (Goffman, 2010, s. 410).

Taki żywy charakter rozmowy, zdaniem autora, ani nie zmusza nas w przedstawianiu różnych wersji, że tak powiem, miękkiej rzeczywistości i jej nawarstwień (czyli to, co uważamy za obiektywne i realne), by za wszelką cenę osiągnąć jakiś konsensus, ani nie uwalnia naszej odpowiedzialności za pilnowanie takiego oglądu rzeczy, iż pod różnymi interpretacjami znajduje się twarda rzeczywistość, niedostępna w całości ani samemu rozumowi, ani samej intuicji, ani samej logice, ani samej estetyce.

\section{Zakończenie}

Można się oczywiście spierać, jak wielką wartość mają dla nas propozycje Goffmana, lecz nie ulega najmniejszej wątpliwości, że są godne uwagi dla każdego, kto zajmuje się naukami społecznymi oraz humanistycznymi i trudno je pominąć milczeniem. Chociażby przez wzgląd na wskazanie ambiwalentnej roli ramy, sceny i występu jako „schematu interpretacji” zasadniczo usztywniającego zewnętrzne doświadczenia jednostek, a zarazem czyniącego go elementem skutecznej komunikacji oraz jako „performance’u ramowego” pozytywnie 
modyfikującego, a nawet kwestionującego ten schemat, a zarazem narażonego na obniżenie możliwości porozumienia, a nawet brak jakiejkolwiek komunikacji ${ }^{15}$. Ta dynamiczna całość, z jednej strony, jako schemat poznawczy, za pomocą którego możemy poszufladkować określony obszar interakcji, z drugiej strony, jako tryb postępowania w określonym obszarze interakcji, zasadniczo zmienia naszą rolę w przestrzeni rzeczywistej gry między aktorem i widzem oraz między sferą publiczną i sferą prywatną.

Zrozumienie mechanizmu tej całości ${ }^{16}$ (mimo wszystko opartej na poczuciu dynamicznej i trudnej do uzgodnienia jedności, a nie na czysto intelektualnym autorytaryzmie ,jedynego" lub schizofrenicznym dualizmie zadowalającym się redukcją lub hipostazą) powinno skłonić (wszystkich animatorów kultury) do refleksji, iż nie mogą już wpisywać podmiotów w jeden porządek interakcyjny, ustalony „z góry” lub „z dołu”, lecz muszą sobie zdawać sprawę z tego, że szczególnie w demokracji ujawniają się i działają również zasady transgresji i twórczej prospekcji, najczęściej postrzegane jako przejawy spontaniczności, rzadziej jako udawanie spontaniczności, która tak naprawdę jest przygotowana i monitorowana z zewnątrz lub z wewnątrz, za którą kryją się wyraźne ramy interakcji lub reguły ich stosowania wyartykułowane explicite lub implicite.

Jeśli nawet Goffman nie odpowiada wprost na pytanie, jak poruszać się między niedoskonałą rzeczywistością empirii i praktyki a doskonale wykończoną rzeczywistością spekulacji i teorii, to nie ma najmniejszej wątpliwości, że znalezienie drogi pośredniej nie będzie ani łatwe, ani łagodne, i prędzej czy później musi stać się dalekosiężnym celem inicjacji i wzmocnienia takich potrzeb, zdolności i aspiracji, by rozwijać i kształtować prawdziwą świadomość dobrze (dla wszystkich) radzącą sobie na pograniczu światów (realnego i symbolicznego). Jak pisze: „Mogę tylko zasugerować, że ktoś, kto chciałby zwalczać fałszywą świadomość i obudzić ludzi, ukazując im prawdziwe interesy, ma przed sobą wiele pracy, gdyż ich sen jest bardzo głęboki” (Goffman, 2010, s. 14).

15 U Goffmana pojawia się w związku z tym rozróżnienie („podwójna tożsamość”) na „postać” (jako schemat interpretacji osoby i sceny) oraz „wykonawcę” (jako nośnika tego schematu), tym samym mamy kulturowy „zasobnik ram” i społeczny sposób posługiwania się tymi ramami $\mathrm{w}$ toku codziennych interakcji.

16 Znamienna jest tutaj ocena analizy ramowej E. Goffmana, dokonana przez Andrzeja Piotrowskiego, który stwierdził, że jest ona „całościowym sposobem spojrzenia na ład interakcyjny”, obejmujący „zarówno problem kulturowych konwencji rozumienia, jak i poznawczej kompetencji uczestnika pozwalającej mu na stosowanie i przekształcenie układów ramowych w przebiegu interakcji. Analiza ramowa dotyczy zatem w równym stopniu organizacji społecznej i organizacji doświadczenia" (Piotrowski, 1999, s. 57-103). 


\section{Bibliografia}

Bachtin M. (1982). Problemy literatury i estetyki, tłum. W. Grajewski. Wydawnictwo Czytelnik, Warszawa.

Berlin I. (1994). Cztery eseje o wolności, tłum. H. Bartoszewicz, D. Grinberg, D. Lachowska, A. Tanalska-Dulęba. PWN, Warszawa.

Blumer H. (2007). Interakcjonizm symboliczny. Perspektywa i metoda, tłum. G. Woroniecka. Zakład Wydawniczy „Nomos”, Kraków.

Bradley F.H. (1914). Essays on Truth and Reality. Clarendon Press, Oxford.

Dummett M. (1998). Logiczna podstawa metafizyki, tłum. W. Sady. PWN, Warszawa.

Gadamer H.-G. (2004). Prawda i metoda. Zarys hermeneutyki filozoficznej, tłum. B. Baran. Wydawnictwo Naukowe PWN, Warszawa.

Goffman E. (2010). Analiza ramowa. Esej z organizacji doświadczenia, tłum. S. Burdziej. Zakład Wydawniczy „Nomos”, Kraków.

Goffman E. (2000). Człowiek $w$ teatrze życia codziennego, tłum. H. Datner-Śpiewak, P. Śpiewak. Wydawnictwo KR, Warszawa.

Goffman E. (1981). Forms of Talk. University of Pennsylvania Press, Philadelphia.

James W. (1998). Pragmatyzm: nowe imię paru starych stylów myślenia, tłum. J. Prokopiuk.

Wydawnictwo KR, Warszawa.

Kartezjusz (2006). Medytacje o filozofii pierwszej, tłum. J. Hartman. Wydawnictwo Zielona Sowa, Kraków.

Piotrowski A. (1999). Ład perspektyw analitycznych w twórczości Ervinga Goffmana. „Kultura i Społeczeństwo”, t. 31, nr 3, s. 57-103.

Platon (1951). Timaios, Kritias, tłum. W. Witwicki. PWN, Warszawa.

Prigogine I., Stengers I. (1990). Z chaosu ku porządkowi. Nowy dialog człowieka z przyroda, tłum. K. Lipszyc. Państwowy Instytut Wydawniczy, Warszawa.

Tischner J. (1998). Filozofia dramatu. Wprowadzenie. Wydawnictwo Znak, Kraków. 